\title{
Analisis Penatalaksanaan Interaksi Sosial pada Anak Autis dengan Menggunakan Metode Social Story di Klinik Shally Autis Center Palembang Tahun 2020
}

\author{
Dewi Puspita Sari, Ayu Novitrie*, Latifah \\ Universitas Kader Bangsa Palembang \\ *Correspondence email: ayu.novitrie.an@gmail.com
}

\begin{abstract}
Abstrak. Autisme adalah keadaan yang disebabkan oleh kelainan dalam perkembangan yang ditandai dengan kelainan dalam interaksi sosial, komunikasi dan perilaku yang sangat kaku dan pengulangan perilaku, sedangkan interaksi sosial sangat dibutuhkan dalam kehidupan sehari - hari anak autis agar dapat hidup layaknya seperti orang lain. Tujuan dari penelitian ini adalah untuk mengetahui hubungan kontak mata, pemahaman, emosi, dan bicara terhadap interaksi sosial anak autis. Penelitian ini bersifat survei analitik dengan desain Cross Sectional. Populasi dalam penelitian ini adalah seluruh pasien yang brdiagnosa autis di klinik Shally Autis Center Palembang yang berjumlah 60 anak. Sampel dalam penelitian ini adalah seluruh total populasi yaitu 60 anak. Hasil penelitian di peroleh ada hubungan antara kontak mata, pemahaman, emosi, dan bicara dengan interaksi sosial anak autis di klinik Shally Autis Center Palembang Tahun 2020. Di akhir penelitian di sarankan kiranya terapis dalam meningkatkan interaksi sosial anak autis harus memperhatikan kontak mata, pemahaman, emosi, dan bicara untuk di majukan perkembangannya menjadi lebih baik.
\end{abstract}

Kata kunci: Autis; Social Story; Interaksi Sosial

Abstract. Autism is a condition caused by internal disorders. A development characterized by abnormalities in social interactions, communication and very rigid behavior and repetition of behavior, while social interactions are needed in the daily life of children with autism in order to live like everyone else. The purpose of this study was to determine the relationship between eye contact, understanding, emotions, and speech on the social interactions of children with autism. This research is an analytic survey with a Cross sectional design. The population in this study were all 60 patients diagnosed with autism at the Shally Autis Center palembang. the sample in this study was the total of population, namely 60 children. The results of the study found that there was a relationship between eye contact, understanding, emotions, and speech with the social interaction of children with autism at the Shally Autis Center Palembang clinic in 2020. At the end of the study it is suggested that therapists in increasing social interaction of children with autism should pay attention to aye contact, understanding, emotion, and speech to be promoted for better development.

Keywords: Autism; Social Story; Social Interaction

\section{PENDAHULUAN}

Anak - anak akan melewati beberapa tahap perkembangan yang ikut mempengaruhi perilaku mereka. Tak jarang perubahan perilaku yang dialami anak dianggap sebagai sebuah fase yang akan berlalu dengan sendirinya. Padahal, beberapa perubahan perilaku itu bisa menjadi gejala dari adanya gangguan mental yang dialami anak. Gangguan mental adalah suatu penyakit atau kondisi yang mempengaruhi pikiran manusia, yang ditandai dengan perilaku, suasana hati, perasaan dan pikiran yang tak menentu (Maslim, 2001).

Istilah gangguan mental masa kanak - kanak berarti semua gangguan mental yang dapat di diagnosis dan muncul di masa kanak - kanak misalnya gangguan attention-deficit / hyperactivity disorder (ADHD), gangguan sindrom Tourette, gangguan perilaku, suasana hati dan kecemasan, gangguan spectrum autisme, gangguan penggunaan zat dan sebagainya (Suryana, 2005).

World Health Organization International Classification of Diseases (ICD-10) mendefinisikan autis sebagai adanya keabnormalan dan atau gangguan perkembangan yang muncul sebelum usia tiga tahun dengan tipe karakteristik tidak normalnya tiga bidang yaitu interaksi sosial, komunikasi, dan perilaku (World Health Organization, 2000).

Menurut Veskarisyanti (2008) dalam bahasa Yunani dikenal kata autis "auto" berarti sendiri ditujukan kepada seseorang ketika menunjukkan gejala hidup dalam dunianya sendiri atau mempunyai dunia sendiri. Jadi salah satu ciri dari anak autis adalah suka menyendiri walaupun di tengah keramaian bahkan terkdang anak autis suka merasa terganggu dengan keramaian baik suara yang berisik atau jumlah orang yang banyak yang membuat anak autis menjadi gelisah di tengah keramaian tersebut. Pada dasarnya, autisme mengganggu perilaku seseorang dalam tiga domain utama yakni sosial, komunikasi dan tingkah laku yang berulang - ulang. Saat ini autisme disebut sebagai gangguan ASD (Autisme Spectrum Disorder) sebab tingkat keparahan dan gejala yang terjadi pada tiap penyandang autis berbeda - beda.

Beberapa penelitian terdahulu mengungkapkan bahwa salah satu penyebab anak menjadi autis yaitu 
Dewi Puspita Sari, Ayu Novitrie dan Latifah, Analisis Penatalaksanaan Interaksi Sosial pada Anak Autis dengan Menggunakan Metode Social Story di Klinik Shally Autis Center Palembang Tahun 2020

dikarenakan adanya gangguan biokimia di tubuh anak yang secara berlebihan (Judarwanto, 2008).

Dalam dekade terakhir ini jumlah anak autis semakin meningkat dari tahun ke tahun. Menurut UNESCO prevlensi penyandang autisme di seluruh dunia pada tahun 2011 adalah 6 di antara 1000 orang. Menurut Mohammad Nelwansyah direktur eksekutif Rumah Autis menyatakan jumlah penderita autis di Indonesia di awal tahun 2000-an prevalensi 1:1000 kelahiran, sedangkan dari tahun 2010 sampai tahun 2015 prevalensinya meningkat menjadi 1,68: 1000 kelahiran. Sedangkan menurut Badan Penelitian Statistik (BPS) jumlah anak autis di Indonesia dari tahun 2010 - 2016 mencapai 140.000 anak.

Berdasarkan dokumentasi klinik Shally Autis Center Palembang jumlah anak autis yang ada di klinik sebanyak 60 anak pada tahun 2020 ini. Angka ini terjadi peningkatan, di awal klnik berdiri tahun 2013 pasien autis hanya berjumlah 16 orang, total bertambahnya pasien autis di klinik adalah sebanyak 44 pasien selama tujuh tahun klinik berdiri.

Semakin meningkatnya jumlah anak autis di dunia, di Indonesia dan juga di klinik Shally Autis Center Palembang para orang tua harus bisa lebih memahami dan mengikuti perkembangan anaknya. Oleh sebab itu penanganan anak autis harus dilakukan sedini mungkin begitu ada gejala yang tampak dari anak. Penanganan autis baiknya dilakukan secara komprehensif yang melibatkan beberapa para ahli dari multidisiplin ilmu yang berkaitan dengan autis salah satunya terapis perilaku. Salah satu perkembangan anak autis yang harus diperhatikan dan di kembangkan secepat mungkin yaitu interaksi sosial kepada orang dan lingkungan sekitarnya. Karena dari interaksi sosial yang baik di harapkan anak autis dapat hidup layaknya orang lain secara pergaulan dan dapat diterima dalam masyarakat secara sosial.

Interaksi sosial anak autis dapat di ajarkan secara awal oleh terapis perilaku yang nantinya di ajarkan oleh terapis kepada orang tua dan keluarga untuk dilakukan di rumah kepada anak autis tersebut agar dapat membantu mempercepat kemajuan perkembangan sosialnya. Salah satu intervensi pembelajaran interaksi sosial untuk anak autis dapat menggunakan metode Social Story. Metode social story merupakan salah satu jenis intervensi dengan bantuan media gambar dan tulisan. Social story berisi kegiatan pada situasi tertentu dan mencakup dimana kegiatan itu berlangsung, kapan peristiwa terjadi, siapa yang terlibat, apa yang akan terjadi di situasi tersebut, serta dampak yang akan di timbulkan (Crozier et al, 2007).

Metode ini akan memberikan informasi yang tidak di pahami atau terlewatkan oleh individu mengenai situasi tertentu secara jelas dan nyata mengenai suatu situas, penyebab, dan akibatnya lewat kalimat yang mengandung penggambaran situasi, penggambaran keadaan internal yang di alami karakter cerita, dan penjelasan mengenai jenis-jenis respon yang sesuai (Novita, 2010).

Social story menggambarkan situasi, keterampilan, atau konsep dalam hal sosial dengan isyarat, perspektif, dan tanggapan umum yang relevan dalam gaya dan format yang ditetapkan secara khusus. Social story dapat menguraikan hal - hal rutin yang umum baik dalam menjelaskan pikiran, pernyataan, dan tindakan dari anak - anak ASD (Gray, 2007).

Gray \& Garrand (1993) memperkenalkan metode social story dalam bidang pendidikan untuk anak - anak berkebutuhan khusus. Social story, dengan gaya belajar secara visual, digunakan untuk mengajar anak - anak dengan autis mengenai keterampilan sosial yang menggunakan cerita yanng mirip dengan situasi yang sebenarnya.

Social story terdiri dari empat sampai enam kalimat yang memberikan gambaran informasi mengenai suatu situasi sosial, kemungkinan reaksi orang lain dalam situasi tersebut dan pernyataan direktif (langsung) mengenai respon sosial yang diharapkan (Yuwanto, 2012 ). Dengan menggunakan metode Social Story yang berupa kartu - kartu bergambar selain fungsinya membentuk pemahaman anak autis tentang interaksi sosial dapat juga membuat anak autis untuk melakukan perintah dari terapis mengikuti gerakan pada gambar dan yang sangat penting dengan sering dan banyaknya gambar dan bentuk yang dilihatkan ke anak akan membantu pembentukan respon, kontak mata, konsentrasi dan emosional anak. Semua ini diharapkan dapat terjadi dengan cepat pada perkembangan anak autis tersebut agar anak dapat berinteraksi dengan orang dan lingkungan sekitar selayaknya orang lain. Yang kita harapkan interaksi sosial di awal yaitu senyum dan jabat tangan kepada orang sekitar.

\section{METODE}

Penelitian ini merupakan penelitian observasional dengan menggunakan pendekatan survei analitik Cross Sectional (potong lintang). Alat ukur yang digunakan berupa kuesioner. Sampel penelitian ini adalah semua anak autis di klinik Shally Autis Center Palembang tahun 2020 yang berjumlah 60 anak autis. Sampel diambil dengan menggunakan teknik total sampling. Analisis data yang digunakan dalam penelitian ini adalah analisis univariat, analisis bivariat, dan analisis multivariat.

\section{HASIL DAN PEMBAHASAN}

Klinik Shally Autis Center Palembang adalah klinik yang memberikan pelayanan terapi untuk anak autis. Penelitian ini menggunakan variabel independen berupa kontak mata, pemahaman, emosi, dan bicara dengan variabel dependen berupa interaksi sosial. Dari 60 orang responden, distribusi frekuensi responden paling banyak berusia 2 tahun yaitu sebanyak 28 orang 
Dewi Puspita Sari, Ayu Novitrie dan Latifah, Analisis Penatalaksanaan Interaksi Sosial pada Anak Autis dengan Menggunakan Metode Social Story di Klinik Shally Autis Center Palembang Tahun 2020

(46,7\%) dengan jenis kelamin laki-laki paling banyak yaitu sebanyak 38 orang $(63,3 \%)$,

Dari 60 orang paling banyak responden yang baik interaksi sosialnya yaitu sebanyak 40 orang $(66,7 \%)$. Dari 60 orang paling banyak respondenyang kontak matanya kurang baik yaitu sebanyak 34 orang $(56,7 \%)$, responden yang pemahamannya baik yaitu sebanyak 40 orang $(66,7 \%)$, responden yang emosinya baik yaitu sebanyak 38 orang $(63,3 \%)$, dan responden yang bicaranya kurang baik yaitu sebanyak 32 orang $(53,3 \%)$.

Tabel 1. Distribusi Frekuensi Responden $(\mathrm{N}=60)$

\begin{tabular}{|c|c|c|c|}
\hline No & Variabel Penelitian & $\mathbf{n}$ & $\%$ \\
\hline \multicolumn{4}{|c|}{ Karakteristik Responden } \\
\hline \multirow[t]{5}{*}{1} & Umur & & \\
\hline & 1. 2 Tahun & 28 & 46,7 \\
\hline & 2. 3 Tahun & 23 & 38,3 \\
\hline & 3. 4 Tahun & 7 & 11,7 \\
\hline & 4. 5 Tahun & 2 & 3,3 \\
\hline \multirow[t]{3}{*}{2} & Jenis Kelamin & & \\
\hline & 1. Laki-Laki & 38 & 63,3 \\
\hline & 2. Perempuan & 22 & 36,7 \\
\hline \multicolumn{4}{|c|}{ Variabel Dependen } \\
\hline \multirow[t]{3}{*}{3} & Interaksi Sosial & & \\
\hline & 1. Kurang Baik & 20 & 33,3 \\
\hline & 2. Baik & 40 & 66,7 \\
\hline \multicolumn{4}{|c|}{ Variabel Independen } \\
\hline \multirow[t]{3}{*}{4} & Kontak Mata & & \\
\hline & 1. Kurang Baik & 34 & 56,7 \\
\hline & 2. Baik & 26 & 43,3 \\
\hline \multirow[t]{3}{*}{5} & Pemahaman & & \\
\hline & 1. Kurang Baik & 20 & 33,3 \\
\hline & 2. Baik & 40 & 66,7 \\
\hline \multirow[t]{3}{*}{6} & Emosi & & \\
\hline & 1. Kurang Baik & 22 & 36,7 \\
\hline & 2. Baik & 38 & 63,3 \\
\hline \multirow[t]{3}{*}{7} & Bicara & & \\
\hline & 1. Kurang Baik & 32 & 53,3 \\
\hline & 2. Baik & 28 & 46,7 \\
\hline
\end{tabular}

Berdasarkan hasil uji stastistik pada alpha 5\% didapatkan p-value 0,001 untuk variabel kontak mataartinya ada hubungan yang signifikan antara kontak mata dengan interaksi social di Klinik Shally Autis Center Palembang Tahun 2020, p-value 0,000 untuk variabel pemahaman yang artinya ada hubungan yang signifikan antara pemahaman dengan interaksi social di Klinik Shally Autis Center Palembang Tahun 2020, pvalue 0,000untuk variabel Emosi yang artinya ada hubungan yang signifikan antara emosi dengan interaksi social di Klinik Shally Autis Center Palembang Tahun 2020, p-value 0,001 untuk variabel bicara yang artinya ada hubungan yang signifikan antara bicara dengan interaksi social di Klinik Shally Autis Center Palembang Tahun 2020 (Tabel 2).

Tabel 2. Hubungan antara Variabel Independen dengan Variabel Dependen $(\mathrm{N}=60)$

\begin{tabular}{|c|c|c|c|c|c|c|c|}
\hline \multirow{3}{*}{ Variabel } & \multicolumn{4}{|c|}{ Interaksi Sosial } & \multirow{3}{*}{$\begin{array}{c}\text { Total } \\
\mathrm{N}\end{array}$} & \multirow{3}{*}{$\begin{array}{c}\text { OR } \\
(95 \%)\end{array}$} & \multirow{3}{*}{$\begin{array}{c}p \\
\text { value }\end{array}$} \\
\hline & \multicolumn{2}{|c|}{ Kurang baik } & \multicolumn{2}{|c|}{ Baik } & & & \\
\hline & $\mathbf{n}$ & $\%$ & $\mathbf{n}$ & $\%$ & & & \\
\hline \multicolumn{8}{|l|}{ Kontak Mata } \\
\hline - Kurang Baik & 18 & 52,9 & 16 & 47,1 & 34 & \multirow{2}{*}{$\begin{array}{c}6,882 \\
(1,751-27,050)\end{array}$} & \multirow[t]{2}{*}{0,001} \\
\hline - Baik & 2 & 7,7 & 24 & 92,3 & 26 & & \\
\hline \multicolumn{8}{|l|}{ Pemahaman } \\
\hline - Kurang Baik & 20 & 100 & 0 & 0 & 20 & \multirow{3}{*}{ - } & \multirow[t]{2}{*}{0,000} \\
\hline - Baik & 0 & 0 & 40 & 100 & 40 & & \\
\hline \multicolumn{7}{|l|}{ Emosi } & \\
\hline - Kurang Baik & 20 & 90,9 & 2 & 9,1 & 22 & 0,091 & \multirow{2}{*}{0,000} \\
\hline - Baik & 0 & 0 & 38 & 100 & 38 & $(0,024-0,341)$ & \\
\hline \multicolumn{8}{|l|}{ Bicara } \\
\hline - Kurang Baik & 18 & 56,2 & 14 & 43,8 & 32 & 7,875 & \multirow[t]{2}{*}{0,001} \\
\hline - Baik & 2 & 9,3 & 26 & 92,9 & 30 & $(2,001-30,991)$ & \\
\hline
\end{tabular}

Berdasarkan hasil analisis regresi logistic didapat 2 variabel yang bermakna secara statistik hubungannya dengan interaksi sosial. Kedua variabel tersebut adalah variabel Bicara $\mathrm{RP}=13,246$ (95\% CI : 2,444-71,788) $\mathrm{p}$ value $=0,03$ danvariabel kontak mata $\mathrm{RP}=10,396(95 \%$ CI : $1,878-57,551) \mathrm{p}$-value $=0,007$.

\section{Hubungan Kontak Mata Dengan Interaksi Sosial}

Hasil analisis hubungan kontak mata dengan interaksi sosial, dapat dilihat bahwa responden yang memiliki kontak mata kurang baik dan memiliki interaksi sosial kurang baik (52,9\%). Sedangkan responden yang memiliki kontak mata yang baik dan memiliki interaksi sosial yang kurang baik $(7,7 \%)$. Dari uji statistik dapat diketahui bahwa p-value $=0.001$ atau $<0.05$. Dapat disimpulkan bahwa ada hubungan antara kontak mata dengan interaksi sosial. Dari hasil analisis bivariate diketahui bahwa responden yang memiliki kontak mata yang kurang baik berisiko 6,8 kali mengalami interaksi sosial yang kurang baik dibandingkan dengan responden yang memiliki kontak mata yang baik.

Dalam interaksi sosial kontak mata sangat dibutuhkan karena kontak mata merupakan awal dari anak autis untuk memulai sutau interaksi dengan orang lain. Dengan adanya kontak mata akan membuat ketertarikan atau memunculkan respon anak autis untuk memulai interaksi, mungkin ketertarikan dengan apa yang di lihatnya pada orang tersebut atau dengan adanya kontak mata anak autis ke orang lain saat orang tersebut memanggil anak menoleh dan melihat ke arah orang tersebut sehingga akan memunculkan respon anak untuk berinteraksi sosial baik dengan senyuman atau membalas sapaan orang yang memanggilnya tersebut.

Menurut Carbone, et al (2013), kontak mata merupakan aktivitas sosial yang paling mendasar dan penting karena kontak mata berfungsi untuk mengatur tatap muka pada masing - masing anak dalam berinteraksi sosial. Kontak mata yang baik akan mendukung interaksi sosial yang baik, sebaliknya kontak mata yang buruk berdampak pada kurangnya interaksi sosial.

Penelitian yang dilakukan Rahayu (2014) yang meneliti tentang Kemampuan Komunikasi Anak Autis Dalam berinteraksi Sosial, menunjukkan bahwa dimana AS belum bisa fokus, perilaku tersebut mempengaruhi cara berinteraksi sosial. Apabila di panggil anak hanya menoleh sebentar sehingga belum dapat berinteraksi sosial dengan baik sebagaimana mestinya. Dan ketika komunikasi berlangsung kontak mata yang dilakukan AS masih memerlukan bimbingan karena belum bisa melakukan kontak mata secara spontan terhadap lawan bicara.

Penelitian yang dilakukan Hendarko dan Anggraika (2018) yang meneliti tentang Efektivitas Teknik Prompting Dan Positive Reinforcement Untuk Meningkatkan Frekuensi Kontak Mata Pada Anak 
Dewi Puspita Sari, Ayu Novitrie dan Latifah, Analisis Penatalaksanaan Interaksi Sosial pada Anak Autis dengan Menggunakan Metode Social Story di Klinik Shally Autis Center Palembang Tahun 2020

Prasekolah Dengan Autisme menunjukkan adanya peningkatan frekuensi perilaku kontak mata pada A, dari jumlah kontak mata sebanyak o atau 1 kali hingga menjadi 8 kali dalam satu sesi (10 kali percobaan). Pada saat pemberian intervensi di sesi - sesi awal A sulit untuk memperhatikan dan diajak beraktivitas bersama peneliti. Akan tetapi, pada sesi - sesi berikutnya A terlihat lebih tenang dan kooperatif.

Pada penelitian ini, peneliti melakukan penelitian sebanyak 16 kali pertemuan dengan anak autis, dilakukan hanya anak autis bersama peneliti saja di dalam ruangan menggunakan metode social story. Metode social story ini bertujuan untuk mendapatkan kontak mata anak autis menjadi lebih baik dan lebih lama dalam menatap orang ataupun lingkungan sekitar. Di awal pertemuan kontak mata dari setiap anak autis berbeda - beda ada yang sangat singkat dan singkat dalam menatap orang lain, ini juga tergantung dari jenis autis yang di alami oleh anak mulai dari autis ringan, autis sedang dan autis berat. Setelah dilakukan peelitian 16 kali pertemuan dengan pemberian metode social story ada perkembangan kontak mata dari setiap anak baik sedikit maupun banyak, contohnya di awal kontak mata hanya 3 detik menjadi 10 - 15 detik, kontak mata yang singkat 3 detik anak sulit untuk berinteraksi karena melihat ke orang lain sangat singkat dan cepat menoleh ke arah lain, setelah kontak mata menjadi 10 - 15 detik maka ada penambahan lamanya dalam melihat atau menatap orang lain baik yang di lihat sengaja atau karena dipanggil orang tersebut bahkan ada anak dapat tersenyum. Disini terlihat kontak mata dapat memunculkan interaksi sosial dan kontak mata mempunyai hubungan terhadap interaksi sosial anak autis.

\section{Hubungan Pemahaman Dengan Interaksi Sosial}

Hasil analisis hubungan pemahaman dengan interaksi sosial, dapat dilihat bahwa terdapat responden yang memiliki pemahaman kurang baik dan memiliki interaksi sosial kurang baik (100\%). Sedangkan responden yang memiliki pemahaman yang baik dan memiliki interaksi sosial yang kurang baik (0\%). Dari uji statistik dapat diketahui bahwa p-value $=0.000$ atau < 0.05. Dapat disimpulkan bahwa ada hubungan antara pemahaman dengan interaksi sosial.

Dalam interaksi sosial pemahaman juga dibutuhkan untuk melanjutkan interaksi menjadi lebih lama dan untuk mengerti interaksi sosial yang sedang terjadi bagi anak autis. Dengan adanya pemahaman anak autis yang baik membuat interaksi sosial akan lebih mempunyai arti, contohnya adanya orang yang menyapa anak dengan kata "Hai" jika anak autis paham sapaan orang yang menyapanya kemungkinan anak autis juga akan membalas sesuai dengan sapaan orang tersebut dengan kata "Hai juga", disini terlihat interaksi lebih mempunyai makna.
Peters (2009) mengemukakan bahwa autis merupakan suatu gangguan yang perkembangan, gangguan pemahaman, gangguan pervasive, dan bukan suatu bentuk penyakit mental. Autis mempunyai gaya kognisi yang berbeda, pada dasarnya otak mereka memproses informasi dengan cara berbeda. Mereka mendengar, melihat, dan merasa, tetapi otak mereka memperlakukan informasi dengan cara yang berbeda, ini sebabnya autis mengacu pada gangguan komunikasi dan interaksi sosial.

Penelitian yang dilakukan Rahayu (2014) yang meneliti tentang Kemampuan Komunikasi Anak Autis Dalam Berinteraksi Sosial, menunjukkan bahwa kecepatan AS dalam merespon masih kurang dan tidak memahami saat berkomunikasi dan berinteraksi , terkadang AS mampu merespon tetapi respon yang diberikan AS belum sesuai dengan topik, perilaku yang sering di ulang AS saat melakukan komunikasi berupa gerakkan tangan yang selalu mencari - cari sesuatu untuk dipegang, dalam merespon pun AS membutuhkan bimbingan, perilaku tersebut mempengaruhi cara berinteraksi sosial.

Pada penelitian ini, peneliti melakukan penelitian sebanyak 16 kali pertemuan dengan anak autis, dilakukan hanya anak autis bersama peneliti saja di dalam ruangan menggunakan metode social story. Metode social story ini juga bertujuan untuk mendapatkan pemahaman anak autis menjadi lebih baik dalam berinteraksi dengan orang lain. Di awal pertemuan pemahaman dari setiap anak autis berbeda beda dalam berinteraksi dengan orang lain, ada anak autis yang belum paham sama sekali dan ada juga yang sdikit paham. Setelah dilakukan pemberian metode social story terhadap anak, ada kemajuan perkembangan pemahaman anak walupun kemajuan perkembangan pemahaman anak autis juga berbeda - beda, contohnya dari yang tidak mengerti sama sekali dalam berinteraksi dengan orang lain sekarang anak sudah cukup paham untuk membalas interaksi yaitu ada orang yang menyapa dengan memanggi nama anak dan melambaikan tangan, anak menoleh dan membalas dengan melambaikan tangan juga. Disini terlihat dengan adanya pemahaman pada anak autis membuat interaksi sosial menjadi berbalas dan bermakna sehingga pemahaman mempunyai hubungan terhadap interaksi sosial anak autis.

\section{Hubungan Emosi Dengan Interaksi Sosial}

Hasil analisis hubungan emosi dengan interaksi sosial, dapat dilihat bahwa responden yang memiliki emosi kurang baik dan memiliki interaksi sosial kurang baik terdapat $(90,9 \%)$. Sedangkan responden yang memiliki emosi yang baik dan memiliki interaksi sosial yang kurang baik (0\%). Dari uji statistik dapat diketahui bahwa p-value $=0.000$ atau $<0.05$. Dapat disimpulkan bahwa ada hubungan antara emosi dengan interaksi sosial. Karena terdapat $25 \%$ cell yang bernilai 0 maka 
Dewi Puspita Sari, Ayu Novitrie dan Latifah, Analisis Penatalaksanaan Interaksi Sosial pada Anak Autis dengan Menggunakan Metode Social Story di Klinik Shally Autis Center Palembang Tahun 2020

nilai RP yang muncul hanya pada kategori emosi baik. Pada penelitian ini, responden yang memiliki emosi yang baik dapat menurunkan risiko sebesar 0,09 kali mengalami interaksi sosial yang kurang baik.

Dalam interaksi sosial emosi yang baik sangat dibutuhkan agar interaksi sosial dapat bermakna dan berlangsung lama. Dengan adanya emosi yang baik saat interaksi sosial berlangsung anak autis akan terlilhat tenang dan tidak adanya marah - marah maupun menangis dan interaksi sosial akan dapat berlangsung lama, serta anak autis dapat juga menyampaikan keinginannya dengan ekspresi wajah.

Anak autis banyak menunjukkan emosi negatif, anak autis juga sangat jarang menunjukkan rasa senang secara langsung terhadap pengaruh langsung temannya, seperti memberikan senyum pada orang lain yang menaruh perhatian kepadanya. Jadi, yang hilang pada anak autis adalah emosi yang merupakan salah satu bagian penting dalam interaksi timbal balik (Bandi, 2009).

Ekspresi wajah merupakan perilaku non verbal utama yang mengekspresikan keadaan emosional seseorang (Mulyana, 2011). Penelitian yang dilakukan Rahayu (2014) yang meneliti tentang Kemampuan Komunikasi Anak Autis Dalam Berinteraksi Sosial, menunjukkan bahwa dimana AS belum mempunyai kemampuan dalam ekspresi wajah atau emosi, saat komunikasi atau interaksi berlangsung AS terkadang menunjukkan ekspresi tertawa, perilaku tersebut mempengaruhi interaksi sosial AS terhadap lingkungan sekitar.

Pada penelitian ini, peneliti melakukan penelitian sebanyak 16 kali pertemuan dengan anak autis, dilakukan hanya anak autis bersama peneliti saja di dalam ruangan menggunakan metode social story. Metode social story ini bertujuan untuk membuat emosi anak autis menjadi lebih baik sehingga interaksi sosial mempunyai makna dan berlangsung lama. Di awal pertemuan emosi dari setiap anak autis berbeda - beda ada yang menangis saat di sapa atau di sentuh orang lain untuk berinteraksi. Setelah dilakukan penelitian 16 kali pertemuan dengan pemberian metode social story ada perkembangan emosi dari setiap anak baik sedikit maupun banyak, contohnya di awal ada anak yang suka menangis saat disentuh oleh orang lain untuk berinteraksi sosial, setelah 16 kali pertemuan anak tidak lagi menangis di sentuh untuk berinteraksi yaitu ada orang yang menyapa dengan memegang tangan anak, anak melihat ke orang tersebut dan senyum ke orang tersebut. Disini terlihat emosi dapat membuat interaksi sosial menjadi bermakna dengan situasi yang tenang dan emosi mempunyai hubungan terhadap interaksi sosial anak autis.

\section{Hubungan Bicara Dengan Interaksi Sosial}

Hasil analisis hubungan bicara dengan interaksi sosial, dapat dilihat bahwa responden yang memiliki kemampuan bicara kurang baik dan memiliki interaksi sosial kurang baik $(56,2 \%)$. Sedangkan responden yang memiliki kemampuan bicara yang baik dan memiliki interaksi sosial yang kurang baik $(9,3 \%)$. Dari uji statistik dapat diketahui bahwa p-value $=0.001$ atau < 0.05. Dapat disimpulkan bahwa ada hubungan antara bicara dengan Interaksi Sosial. Pada penelitian ini, diketahui bahwa respoden yang memiliki kemampuan bicara yang kurang baik memiliki risiko 7,8 kali untuk mengalami interaksi sosial yang kurang baik dibandingkan dengan responden yang memiliki kemampuan bicara yang baik.

Dalam interaksi sosial bicara yang baik sangat dibutuhkan agar interaksi sosial dapat terlihat sempurna dengan adanya komunikasi 2 arah. Dengan adanya bicara anak autis yang baik saat interaksi sosial berlangsung maka akan terjadinya komunikasi antara anak autis dengan lawan bicara, anak autis juga dapat menyampaikan keinginannya dengan bicara, disini akan terlihat interaksi lebih baik atau sempurna.

Anak autis mengalami beberapa gangguan antara lain pada cerebellum yang berfungsi dalam sensorik, mengingat, perhatian, dan kemampuan bahasanya. Sekitar 50\% anak autis mengalami keterlambatan dalam bahasa dan berbicara (Azwandi, 2005). Banyak orang yang tidak memahami ucapan anak autis apabila di ajak berbicara. Anak autis sering mengoceh tanpa arti yang dilakukkan secara berulang - ulang dengan bahasa yang tidak dimengerti orang lain, berbicara tidak digunakan untuk berkomunikasi, serta senang meniru atau membeo (Sunarya, 2004).

Penelitian yang dilakukan Rahayu (2014) yang meneliti tentang Kemampuan Komunikasi Anak Autis Dalam Berinteraksi Sosial, menunjukkan bahwa AS sudah mampu berbicara tetapi berbicaranya belum bisa digunakan untuk berkomunikasi dan berinteraksi, dari hasil penelitian di dapati bahwa AS lebih memperlihatkan komunikasi melalui sentuhan dan gerakan tubuh, komunikasi secara verbalnya hanya sebatas menjawab dan memanggil nama untuk yang lebih sulit AS belum mampu karena masih mengalami keterbatasan dalam bicara, AS dalam mengikuti percakapan masih pasif atau terkadang justru hanya diam saja, hal ini mempengaruhi komunikasi dan interaksi sosial AS terhadap lingkungan sekitar.

Pada penelitian ini, peneliti melakukan penelitian sebanyak 16 kali pertemuan dengan anak autis, dilakukan hanya anak autis bersama peneliti saja di dalam ruangan menggunakan metode social story. Metode social story ini bertujuan untuk membantu perkembangan bicara anak autis menjadi lebih baik sehingga adanya komunikasi 2 arah saat interaksi sosial berlangsung. Di awal pertemuan bicara dari setiap anak autis berbeda-beda ada yang tidak bisa bicara sama sekali dan ada yang bisa 1,2 maupun bicara. Setelah dilakukan penelitian 16 kali pertemuan dengan pemberian metode social story ada perkembangan bicara 
Dewi Puspita Sari, Ayu Novitrie dan Latifah, Analisis Penatalaksanaan Interaksi Sosial pada Anak Autis dengan Menggunakan Metode Social Story di Klinik Shally Autis Center Palembang Tahun 2020

dari setiap anak baik sedikit maupun banyak dan anak di ajarkan berbicara dalam berinteraksi, contohnya di awal ada anak yang hanya dapat berbicara satu kata "menjawab pertanyaan dengan kata baik" saat berinteraksi sosial, setelah 16 kali pertemuan dan di ajarkan untuk bisa menambah jawaban, anak di tanya denga sapaan apa kabar? Anak menajwab dengan baik baik saja. Disini terlihat bicara dapat membuat interaksi sosial menjadi lebih sempurna dengan adanya komunikasi 2 arah yang lebih baik dan bicara mempunyai hubungan terhadap interaksi sosial anak autis.

\section{SIMPULAN}

Dari hasil penelitian dan pembahasan, maka dapat disimpulkan sebagai berikut:

1. Ada hubungan yang signifikan antara kontak mata dengan interaksi sosial di Klinik Shally Autis Center Palembang Tahun 2020.

2. Ada hubungan yang signifikan antara pemahaman dengan interaksi sosial di Klinik Shally Autis Center Palembang Tahun 2020.

3. Ada hubungan yang signifikan antara emosi dengan interaksi sosial di Klinik Shally Autis Center Palembang Tahun 2020.

4. Ada hubungan yang signifikan antara bicara dengan interaksi sosial di Klinik Shally Autis Center Palembang Tahun 2020.

5. Variabel bicara merupakan variabel yang paling dominan mempengaruhi interaksi sosial dan variabel bicara bersama - sama (simultan) dengan variabel kontak mata mempengaruhi interaksi sosial di Klinik Shally Autis Center Palembang.

\section{DAFTAR PUSTAKA}

Azwandi, Y. (2005). Mengenal dan Membantu Penyandang Autis. Jakarta: Departemen Pendidikan Nasional RI.

Bandi, D. (2009). Pendidikan Anak Autistik. Klaten: PT Intan Sejati.

Carbone, V. J, O’Brien, L, Sweeney-Kerwin, E. J, \& Albert, K. M (2013). Teaching Eye Contact to Children With Autism A Conceptual Analysis and Single Case Study. Education and Treatment of Children, 36, 139-159.

Crozier, S, fincant, M. (2007). Effects of Social Story On Prosocial Behavior of Preschool Children With Autism Spectrum Disorder. Journal Autism Dev Disorder, 37, 1803-1814.

Gray, C. (2007). Social Stories. BS Myles, TC Swanson, J Holverstott, \& MM Duncan (Eds.). Autism Spectrum Disorder, A Handbook For Parents and Professionals. (pp 355-357). London: Praeger.

Gray, C \& Garrand, J. D. (1993). Social Stories: Improving Responses of Students With Autism With Accurate Social Information. Focus on Autistic Behavior, 8(1), 1-10.
Hendarko, A.C \& Anggraika, I. (2018).Efektivitas Teknik Prompting dan Positive Reinforcement untuk Meningkatkan Frekuensi Kontak Mata pada Anak Prasekolah dengan Autisme. Jurnal Psikogenesis. Vol 6:2. 176-185.

Judarwanto, W. (2008). Perilaku Makan Anak Sekolah. Medan: Universitas Sumatera Utara.

Maslim, R. (2001). Retardasi Mental dalm Buku Saku Diagnosis Gangguan Jiwa-Rujukan Ringkas dari PPDGJ III. Jakarta. 119-121.

Mulyana, D. (2011). Ilmu Komunikasi. Bandung: PT Rosdakarya.

Novita, S. (2010). Pengaruh Social Stories Terhadap Keterampilan Sosial Anak Dengan Attentiondeficit Hyperactivity Disorder. Jurnal Psikologi, 8, (2), 102-116.

Peters, T. (2009). Panduan Autisme Terlengkap. Jakarta: PT Gramedia Pustaka Utama.

Rahayu, F. (2014). Kemampuan Komunikasi Anak Autis Dalam Interaksi Sosial (Kasus Anak Autis di Sekolah Inklusi, SD Negeri Giwangan Kotamadya Yogyakarta). Skripsi.Ilmu Pendidikan:Universitas Negeri Yogyakarta.

Sunarya, A. (2004). Terapi Autisme, Anak Berbakat, dan Anak Hiperaktif. Jakarta: Progres.

Suryana, A. (2005). Berbagai Masalah Kesehatan Anak dan Balita. Jakarta: Khilma.

Veskarisyanti, G.A. (2008). Terapi Autis Paling Efektif dan Hemat. Yogyakarta: Pustaka Anggrek.

World Health Organization es International Classification of Diseases (ICD-10) (American Psychiatric Association, h. 75, (2000). Diagnostic and Statictical Manual-IV http://www.autisme.info/index.php/terapiautisme/10-jenisterapi-autisme

Yuwanto, L. (2012). Stres Akademik dan Flow Akademik. Jakarta: Dwiputra Pustaka Jaya. 